\title{
HUBUNGAN ANTARA MOTIVASI, BEBAN KERJA, DAN LINGKUNGAN KERJA DENGAN KELELAHAN KERJA
}

\section{THE RELATIONSHIP BETWEEN MOTIVATION, WORKLOAD, AND WORK ENVIRONMENT WITH FATIGUE}

\author{
Bintang Mareeta Dewi \\ Rumah Sakit Islam Ponorogo \\ E-mail: bintang.mareeta@gmail.com
}

\begin{abstract}
Cooperative is a form of business entity that develope steadily and manages different businesses including industrial sector. Koperasi KAREB is a cooperative engaged in different sector such as industrial sector in the form of Processing Units engaged in the tobacco processing. The development of industrial sector made Cooperative KAREB exert machines and manpower in the production process to achieve maximum output. The utilization of manpower can cause the onset of fatigue. Work fatigue becomes the basic complaint to be felt by every labor and can be caused by many different factors. The purpose of this research is to analyze the relationship between motivation, workload, and work environment with fatigue in the Unit Processing Koperasi KAREB. This research is an observational analytic research with cross sectional design. The population of this research is labors in Unit Processing Koperasi KAREB as many as 46 labors with the sample of 35 people that are taken using simple random sampling method. Data retrieval technique used questionnaires. Data analysis technique used Spearman Correlation. The results showed that $28.6 \%$ workers suffered mild fatigue, $65.7 \%$ workers suffered average fatigue, and $5.7 \%$ workers suffered severe fatigue. Statistical tests indicate that there is a relationship between motivation $(p=0.004)$, workload $(p=0.031)$, and temperature perception $(p=0.042)$ with fatigue. While, there is no relationship between noise and fatigue. It can be conclude that fatigue is influenced by some factors such as motivation, workload, and temperature of the working environment.
\end{abstract}

Keywords: fatigue, motivation, noise, temperature, workload

\begin{abstract}
ABSTRAK
Koperasi merupakan salah satu bentuk badan usaha yang perkembangannya terus mengalami peningkatan hingga mampu mengelola berbagai bidang usaha tidak terkecuali di bidang industri. Koperasi KAREB adalah koperasi yang bergerak di berbagai bidang usaha, salah satunya yaitu di bidang industri berupa Unit Processing yang bergerak di bidang pengolahan tembakau. Perkembangan sektor industri membuat Koperasi KAREB mengerahkan tenaga mesin dan manusia dalam proses produksinya untuk mencapai output maksimal. Pemanfaatan tenaga manusia ini dapat menyebabkan terjadinya kelelahan kerja dan setiap pekerja berisiko mengalami kelelahan termasuk pekerja di Unit Processing Koperasi KAREB. Tujuan dari penelitian ini adalah untuk menganalisis hubungan antara motivasi, beban kerja, dan lingkungan kerja dengan kelelahan kerja di Unit Processing Koperasi KAREB. Penelitian ini adalah penelitian observasional analitik dengan rancang bangun cross sectional. Populasi penelitian yaitu pekerja Unit Processing Koperasi KAREB. Sampel dalam penelitian ini berjumlah 35 orang yang merupakan sebagian pekerja Unit Processing Koperasi KAREB dan diambil menggunakan metode simple random sampling. Teknik pengambilan data menggunakan kuesioner, sedangkan teknik analisis data menggunakan Korelasi Spearman. Hasil penelitian menunjukkan 28,6\% pekerja mengalami kelelahan ringan, 65,7\% pekerja mengalami kelelahan sedang, dan 5,7\% pekerja mengalami kelelahan berat. Hasil uji statistik menunjukkan bahwa terdapat hubungan antara motivasi kerja $(p=0,004)$, beban kerja $(p=0,031)$, dan persepsi suhu $(p=0,042)$ dengan kelelahan kerja. Kebisingan tidak ditemukan adanya hubungan dengan kelelahan kerja. Kesimpulan penelitian ini bahwa kelelahan dapat dipengaruhi oleh berbagai faktor antara lain faktor motivasi, beban kerja, dan lingkungan kerja yaitu pada suhu lingkungan kerja.
\end{abstract}

Kata kunci: beban kerja, kebisingan, kelelahan, motivasi, suhu

(C2018 IJOSH. Open access under CC BY NC-SA license doi: 10.20473/ijosh.v7i1.2018.20-29. Received 27 July 2017, received in revised form 2 August 2017, Accepted 10 August 2017, Published: 22 January 2018 


\section{PENDAHULUAN}

Koperasi merupakan salah satu bentuk badan usaha yang perkembangannya terus mengalami peningkatan dan dalam perkembangannya koperasi mampu mengelola berbagai bidang usaha tak terkecuali di bidang industri. Semakin banyak industri yang ada di Indonesia menimbulkan semakin banyaknya risiko yang dihadapi tidak terkecuali pada risiko kesehatan maupun keselamatan kerja. Oleh sebab itu suatu industri harus mengelola lingkungan kerjanya agar dapat menurunkan risiko tersebut. Sikap kritis dunia juga menjadi dorongan bagi industri yang lingkungan kerjanya berpotensi menimbulkan risiko kesehatan maupun keselamatan kerja untuk menerapkan suatu sistem pengelolaan yang aman bagi tenaga kerjanya.

Keselamatan dan Kesehatan Kerja (K3) mengandung nilai perlindungan terhadap tenaga kerja dari kecelakaan dan penyakit akibat kerja sehingga diharapkan dapat mencegah terjadinya kecelakaan kerja maupun penyakit akibat kerja guna meningkatkan produktivitas kerja. Faktor lingkungan kerja yang tidak memenuhi syarat $\mathrm{K} 3$, proses kerja yang tidak aman, dan sistem kerja yang semakin modern dapat menjadi ancaman tersendiri bagi keselamatan maupun kesehatan pekerja. K3 yang merupakan salah satu bagian dari upaya perlindungan tenaga kerja perlu diterapkan pada setiap proses kerja. Hal tersebut dimaksudkan untuk memenuhi tercapainya tujuan penerapan K3 di tempat kerja seperti yang tertera pada Undangundang No. 1 Tahun 1970 tentang Keselamatan Kerja (Tarwaka dan Sudiajeng, 2004).

Perlindungan terhadap tenaga kerja meliputi aspek yang cukup luas, diantaranya adalah perlindungan dalam aspek keselamatan dan kesehatan kerja sesuai dengan Undang-Undang No. 1 Tahun 1970 yang menyatakan bahwa setiap tenaga kerja berhak mendapat perlindungan atas keselamatannya dalam melakukan pekerjaan untuk kesejahteraan hidup dan meningkatkan produksi serta produktivitas nasional. Perlindungan tersebut bertujuan untuk memberikan jaminan keselamatan dan meningkatkan derajat kesehatan tenaga kerja guna menjaga maupun meningkatkan produktivitas tenaga kerja dan perusahaan. Salah satu tujuan pelaksanaan kesehatan kerja adalah pencegahan terhadap timbulnya kelelahan akibat kerja dan peningkatan produktivitas kerja. Tujuan tersebut dapat dicapai apabila didukung oleh lingkungan kerja yang memenuhi syarat kesehatan.
Lelah bagi setiap orang memiliki arti tersendiri dan bersifat subjektif. Kata lelah (fatigue) menunjukkan keadaan tubuh secara fisik dan mental yang berbeda namun semuanya berakibat kepada penurunan performa dan berkurangnya daya tahan tubuh untuk bekerja (Suma'mur, 2009). Definisi kelelahan menurut Tarwaka (2014), adalah suatu mekanisme perlindungan tubuh yang bertujuan untuk menghindarkan tubuh dari kerusakan lebih lanjut sehingga tubuh mampu melakukan pemulihan setelah istirahat.

Kelelahan apabila tidak segera ditangani akan menimbulkan dampak lain seperti kecelakaan kerja. Berdasarkan data dari International Labour Organization (ILO) pada tahun 2013, hampir setiap tahun sebanyak dua juta pekerja meninggal akibat kecelakaan kerja dan data tersebut juga menunjukkan bahwa $32,8 \%$ sampel menderita kelelahan akibat kerja.

Kelelahan akibat kerja dapat timbul karena berbagai faktor. Menurut Grandjean (1993), faktor penyebab kelelahan di industri sangat beragam, di antaranya adalah aktivitas kerja fisik, aktivitas kerja mental, stasiun kerja, kerja statis, kerja monotoni, lingkungan kerja, psikologis, kebutuhan kalori, waktu istirahat dan lain sebagainya. Menurut Suma'mur (2009), akar masalah kelelahan kerja adalah aktivitas kerja fisik, mental, stasiun kerja tidak ergonomis, sikap paksa, kerja statis, monotoni, lingkungan kerja ekstrim, psikologis, kebutuhan kalori kurang, waktu kerja dan istirahat tidak tepat, dan lain sebagainya.

Teori keseimbangan ergonomi menurut Manuaba (2000) dalam Tarwaka dan Sudiajeng (2004), menyatakan bahwa kelelahan kerja diakibatkan oleh ketidakseimbangan antara faktor kapasitas kerja dengan faktor tuntutan tugas. Salah satu faktor dalam kapasitas kerja yaitu motivasi kerja. Tuntutan tugas terdiri dari karakteristik tugas, lingkungan kerja, dan organisasi kerja. Salah satu faktor dalam tuntutan tugas yaitu beban kerja, dan untuk lingkungan kerja contohnya yaitu kebisingan dan suhu lingkungan kerja.

Berbagai faktor yang dapat menyebabkan kelelahan kerja apabila tidak diatasi akan menyebabkan kelelahan akibat kerja dan menimbulkan masalah lain seperti kecelakaan kerja dan menurunkan produktivitas kerja. Salah satu faktor yang berpengaruh secara signifikan terhadap kelelahan kerja yaitu lingkungan kerja. Kelelahan yang disebabkan oleh lingkungan kerja dapat disebabkan oleh lingkungan kerja yang 
kurang memenuhi standar. Lingkungan kerja yang tidak memenuhi standar selain dapat menimbulkan gangguan kesehatan juga dapat menimbulkan gangguan kenyamanan. Gangguan kenyamanan yang dirasakan oleh pekerja dapat mempercepat timbulnya kelelahan sehingga standar yang digunakan untuk mencegah kelelahan akibat lingkungan kerja tidak lagi menggunakan Nilai Ambang Batas (NAB) melainkan lebih kepada tingkat kenyamanan pekerja dengan lingkungan kerjanya (Suma'mur, 2009). Lingkungan kerja yang dimaksud dapat berupa faktor fisik seperti suhu lingkungan dan kebisingan.

Penelitian Lestari pada tahun 2016 menunjukkan adanya pengaruh suhu lingkungan kerja dan kebisingan terhadap timbulnya kelelahan kerja pada pekerja di PT. LPJ Provinsi Kalimantan Timur. Penelitian lain yang juga menunjukkan adanya hubungan antara lingkungan kerja dengan kelelahan kerja yaitu penelitian Hayati pada tahun 2012 yang menunjukkan adanya hubungan antara kebisingan dengan kelelahan kerja pada pekerja di PT. Kusumaputra Santosa Karanganyar.

Faktor lain yang juga berpengaruh terhadap kelelahan kerja yaitu beban kerja. Pekerjaan yang terlalu berat dan berlebih akan mempercepat kontraksi otot tubuh sehingga akan mempercepat terjadinya kelelahan (Suma'mur, 2009). Penelitian Nugraheni (2015), menunjukkan adanya hubungan antara beban kerja dengan kelelahan kerja.

Faktor lain lingkungan kerja dan beban kerja, juga berpengaruh terhadap kelelahan kerja yaitu faktor motivasi kerja. Motivasi kerja seseorang juga dapat mempengaruhi timbulnya kelelahan kerja seperti pada penelitian Setyowati pada tahun 2014 yang menunjukkan adanya hubungan antara motivasi dengan kelelahan kerja. Penelitian lain yang menunjukkan adanya hubungan antara motivasi dengan kelelahan kerja yaitu penelitian Diosma pada tahun 2015.

Setiap pekerja di suatu industri berisiko mengalami kelelahan kerja termasuk pekerja di Unit Processing Koperasi KAREB Bojonegoro. Koperasi Karyawan Redrying Bojonegoro (KAREB) adalah koperasi yang bergerak di berbagai bidang usaha dan memiliki berbagai unit usaha, salah satunya yaitu di bidang industri berupa Unit Processing. Unit tersebut bergerak di bidang pengolahan tembakau dengan proses green leaf threshing and redrying. Proses tersebut menghasilkan produk berupa lamina. Proses produksi di unit tersebut menggunakan tenaga mesin dan juga manusia. Penggunaan tenaga manusia dalam proses produksi tersebut dapat meningkatkan risiko terjadinya kelelahan kerja apabila potensi bahaya yang dapat menyebabkan kelelahan kerja tidak segera ditangani.

Setiap proses produksi di suatu industri mengandung potensi bahaya tertentu yang apabila tidak mendapat perhatian akan menimbulkan kecelakaan kerja maupun penyakit akibat kerja. Potensi bahaya yang dapat menyebabkan kecelakaan kerja maupun penyakit akibat kerja dapat berasal dari berbagai kegiatan atau aktivitas dalam pelaksanaan operasi pekerjaan atau juga berasal dari luar proses kerja.

Unit Processing Koperasi KAREB dalam proses produksinya memiliki potensi bahaya di tempat kerja dan salah satu yang perlu mendapat perhatian yaitu lingkungan kerja yang terdiri dari suhu dan kebisingan yang bersumber dari mesin produksi. Berdasarkan studi pendahuluan, diketahui bahwa beberapa lokasi di Unit Processing memiliki suhu ruangan yang melebihi persyaratan menurut Keputusan Menteri Kesehatan Republik Indonesia Nomor 1405 Tahun 2002, salah satunya yaitu di ruang produksi yang memiliki suhu ruangan $36^{\circ} \mathrm{C}$. Suhu lingkungan kerja di ruangan tersebut dikeluhkan oleh pekerja karena pekerja sering merasa gerah saat bekerja di ruangan tersebut. Kondisi demikian dapat memicu timbulnya kelelahan pada pekerja.

Kondisi lain yang dapat memicu timbulnya kelelahan yaitu suara bising yang ditimbulkan dari mesin produksi. Berdasarkan studi pendahuluan, intensitas kebisingan dalam ruangan produksi yaitu sebesar $81,8 \mathrm{~dB}$. Walaupun intensitas kebisingan tersebut masih di bawah NAB menurut Permenakertrans Nomor 13 tahun 2011, namun kondisi tersebut masih dapat berpotensi mengganggu kenyamanan pekerja karena intensitas kebisingan dalam rentang antara 80 hingga $90 \mathrm{~dB}$ termasuk dalam kategori sangat hiruk dan berpotensi memicu stress hingga berujung pada kelelahan pada pekerja. Berdasarkan hasil wawancara, banyak pekerja yang mengeluhkan adanya gangguan komunikasi akibat suara bising yang ditimbulkan oleh mesin produksi sehingga pekerja harus berbicara dengan suara keras atau bahkan berteriak untuk berkomunikasi dengan pekerja lainnya di ruangan tersebut.

Berdasarkan survei pendahuluan diketahui banyak pekerja yang mengeluhkan gejala kelelahan kerja seperti sering merasa lelah di seluruh tubuh, sakit kepala, kaku di bahu, nyeri punggung, haus, dan pening di saat bekerja maupun setelah bekerja. 
Gejala kelelahan yang dikeluhkan oleh pekerja tersebut dapat timbul akibat berbagai faktor, di antaranya adalah faktor motivasi, beban kerja, dan lingkungan kerja.

Peneliti tertarik untuk menganalisis hubungan antara motivasi kerja, beban kerja, dan lingkungan kerja dengan kelelahan kerja pada pekerja di Unit Processing Koperasi KAREB Bojonegoro. Tujuan dari penelitian ini yaitu menganalisis hubungan antara faktor motivasi, beban kerja, dan lingkungan kerja dengan kelelahan kerja di Unit Processing Koperasi KAREB Bojonegoro.

\section{METODE}

Penelitian ini merupakan penelitian kuantitatif dengan metode pengumpulan data yang digunakan bersifat observasional. Berdasarkan pemilihan waktu pengambilan data, penelitian ini termasuk penelitian cross sectional, sedangkan berdasarkan metode analisis data, penelitian ini merupakan penelitian analitik. Penelitian ini dilaksanakan di kantor Unit Processing Koperasi KAREB Bojonegoro pada Mei-Juni 2017.

Populasi dalam penelitian ini adalah pekerja di Unit Processing Koperasi KAREB yang berjumlah 46 orang. Sampel dalam penelitian ini adalah sebagian pekerja di Unit Processing Koperasi KAREB. Pengambilan sampel menggunakan metode simple random sampling. Besar sampel ditentukan menggunakan rumus Slovin sehingga didapatkan jumlah sampel sebanyak 35 responden.

Penelitian ini menggunakan dua variabel yaitu variabel bebas (independen) dan variabel terikat (dependen). Variabel bebas yang diteliti antara lain motivasi kerja, beban kerja, dan lingkungan kerja yang meliputi kebisingan dan suhu lingkungan kerja. Variabel terikat yaitu kelelahan kerja.

Metode pengumpulan data menggunakan kuesioner. Instrumen yang digunakan yaitu lembar kuesioner untuk mengetahui identitas responden, umur, jenis kelamin, motivasi, dan persepsi tentang lingkungan kerjanya. Selain itu juga digunakan kuesioner subjective feelings of fatigue dari Industrial Fatigue Research Committee (IFRC) untuk mengetahui tingkat kelelahan kerja. Data beban kerja juga diambil menggunakan kuesioner yaitu dengan kuesioner National Aeronautics and Space Administration Task Load Index (NASATLX) yang kemudian akan dihitung skornya sehingga menghasilkan data berupa tingkat beban kerja.
Teknik analisis data dilakukan menggunakan perangkat komputer dengan program pengolah data. Analisis dilakukan melalui analisis univariat dan bivariat. Analisis univariat digunakan untuk memperoleh gambaran distribusi frekuensi atau mendeskripsikan karakteristik dari variabel penelitian. Analisis bivariat dilakukan terhadap dua variabel yang diduga berhubungan atau berkorelasi dengan pengujian statistik. Analisis bivariat dalam penelitian ini dilakukan untuk mengetahui hubungan antara variabel dependen dan independen. Uji statistik yang digunakan dalam penelitian ini disesuaikan dengan jenis skala datanya sehingga uji statistik yang digunakan yaitu korelasi spearman.

\section{HASIL}

\section{Karakteristik Responden}

Responden dalam penelitian ini yaitu 35 orang pekerja di Unit Processing Koperasi KAREB Bojonegoro. Hasil pengumpulan data menggunakan kuesioner, diketahui bahwa sebagian besar responden $(71,4 \%)$ berjenis kelamin laki-laki dan sisanya $(28,6 \%)$ berjenis kelamin perempuan. Umur responden berkisar antara 35-57 tahun.

\section{Kelelahan Kerja}

Kelelahan kerja yang dialami oleh pekerja dibagi tiga kategori yaitu kelelahan ringan, sedang, dan berat. Distribusi pekerja menurut kelelahan kerja dari hasil penelitian dapat dilihat pada Tabel 1.

Tabel 1. Kelelahan Kerja pada Pekerja Unit Processing Koperasi KAREB Bojonegoro Tahun 2017

\begin{tabular}{lcc}
\hline Kelelahan Kerja & Frekuensi (n) & Persentase (\%) \\
\hline Ringan & 10 & 28,6 \\
Sedang & 23 & 65,7 \\
Berat & 2 & 5,7 \\
\hline Total & 35 & 100 \\
\hline
\end{tabular}

Hasil penelitian berdasarkan pengisian kuesioner subjective feelings of fatigue. 35 orang pekerja yang menjadi responden penelitian, sebagian besar pekerja mengalami kelelahan sedang yaitu sebanyak $65,7 \%$ responden. 
Tabel 2. Motivasi Kerja pada Pekerja Unit Processing Koperasi KAREB Bojonegoro Tahun 2017

\begin{tabular}{lcc}
\hline \multicolumn{1}{c}{ Motivasi } & Frekuensi (n) & Persentase (\%) \\
\hline Rendah & 0 & 0 \\
Sedang & 9 & 25,7 \\
Tinggi & 26 & 74,3 \\
\hline Total & 35 & 100 \\
\hline
\end{tabular}

\section{Motivasi}

Motivasi pekerja dibagi dalam tiga kategori yaitu motivasi rendah, sedang, dan tinggi. Distribusi pekerja menurut motivasi kerjanya dapat dilihat pada Tabel 2.

Berdasarkan Tabel 2, dapat dilihat bahwa sebagian besar pekerja $(74,3 \%)$ telah memiliki motivasi kerja yang tinggi dan tidak ada pekerja yang memiliki motivasi rendah.

\section{Beban Kerja}

Beban yang dirasakan oleh pekerja dikategorikan menjadi tiga kategori yaitu ringan, sedang, dan berat. Distribusi pekerja menurut beban kerjanya dapat dilihat pada Tabel 3.

Berdasarkan Tabel 3, dapat diketahui bahwa sebagian besar pekerja merasa memiliki beban kerja berat yaitu sebanyak 23 dari 35 pekerja.

Tabel 3. Beban Kerja pada Pekerja Unit Processing Koperasi KAREB Bojonegoro Tahun 2017

\begin{tabular}{lcc}
\hline Beban Kerja & Frekuensi (n) & Persentase (\%) \\
\hline Ringan & 0 & 0 \\
Sedang & 12 & 34,3 \\
Berat & 23 & 65,7 \\
\hline Total & 35 & 100 \\
\hline
\end{tabular}

Tabel 4. Persepsi Suhu pada Pekerja Unit Processing Koperasi KAREB Bojonegoro Tahun 2017

\begin{tabular}{lcc}
\hline \multicolumn{1}{c}{ Persepsi Suhu } & Frekuensi (n) & Persentase (\%) \\
\hline Tidak Nyaman & 9 & 25,7 \\
Nyaman & 26 & 74,3 \\
\hline Total & 35 & 100 \\
\hline
\end{tabular}

\section{Suhu}

Suhu lingkungan kerja dinilai menggunakan persepsi pekerja tentang suhu ruangan kerjanya dan dikelompokkan menjadi dua kategori yaitu nyaman dan tidak nyaman yang menggambarkan perasaan nyaman atau tidaknya pekerja saat bekerja di ruangan produksi dengan suhu $36^{\circ} \mathrm{C}$. Persepsi pekerja tentang suhu lingkungan kerjanya dapat dilihat pada Tabel 4. Tabel 4 menunjukkan bahwa sebagian besar pekerja $(74,3 \%)$ sudah merasa nyaman dengan suhu di lingkungan kerjanya.

\section{Kebisingan}

Kebisingan di lingkungan kerja dinilai menggunakan persepsi pekerja tentang kebisingan di lingkungan kerjanya dan dikelompokkan menjadi dua kategori yaitu terganggu dan tidak terganggu yang menggambarkan perasaan terganggu atau tidak terganggunya pekerja dengan kebisingan di lingkungan kerjanya yang mencapai intensitas 81,8

Tabel 5. Kebisingan pada Pekerja Unit Processing Koperasi KAREB Bojonegoro Tahun 2017

\begin{tabular}{lcc}
\hline $\begin{array}{c}\text { Persepsi } \\
\text { Kebisingan }\end{array}$ & Frekuensi (n) & Persentase (\%) \\
\hline Terganggu & 18 & 51,4 \\
Tidak terganggu & 17 & 48,6 \\
\hline Total & 35 & 100 \\
\hline
\end{tabular}

Tabel 6. Hubungan Antara Motivasi Kerja dengan Kelelahan Kerja pada Pekerja Unit Processing Koperasi KAREB Bojonegoro Tahun 2017

\begin{tabular}{|c|c|c|c|c|c|c|c|c|}
\hline \multirow{3}{*}{ Motivasi } & \multicolumn{6}{|c|}{ Kelelahan Kerja } & \multirow{2}{*}{\multicolumn{2}{|c|}{ Total }} \\
\hline & \multicolumn{2}{|c|}{ Ringan } & \multicolumn{2}{|c|}{ Sedang } & \multicolumn{2}{|c|}{ Berat } & & \\
\hline & $\mathbf{n}$ & $\%$ & n & $\%$ & $\mathbf{n}$ & $\%$ & $\mathbf{N}$ & $\%$ \\
\hline Rendah & 0 & 0 & 0 & 0 & 0 & 0 & 0 & 0 \\
\hline Sedang & 0 & 0 & 7 & 20 & 2 & 5,7 & 9 & 25,7 \\
\hline Tinggi & 10 & 28,6 & 16 & 45,7 & 0 & 0 & 26 & 74,3 \\
\hline Total & 10 & 28,6 & 23 & 65,7 & 2 & 5,7 & 35 & 100 \\
\hline
\end{tabular}


dB. Tabel 5 menunjukkan bahwa sebagian besar pekerja merasa terganggu dengan kebisingan di lingkungan kerjanya.

\section{Hubungan Motivasi dengan Kelelahan Kerja}

Tabel 6 menunjukkan bahwa kelelahan sedang paling banyak dialami oleh pekerja yang memiliki motivasi tinggi, sedangkan kelelahan berat paling banyak dialami oleh pekerja yang memiliki motivasi sedang. Berdasarkan hasil uji Korelasi Spearman diperoleh nilai $\mathrm{p}$ sebesar 0,004 yang berarti nilai p lebih kecil dari $\alpha(0,05)$ sehingga dapat disimpulkan bahwa terdapat hubungan antara motivasi kerja dengan kelelahan kerja. Nilai koefisien korelasi yaitu sebesar -0,474 yang menunjukkan bahwa kekuatan hubungan antara motivasi kerja dan kelelahan kerja termasuk dalam kategori cukup kuat dan berlawanan arah yakni semakin rendah motivasi kerja maka semakin berat kelelahan yang dirasakan.

\section{Hubungan Beban Kerja dengan Kelelahan Kerja}

Tabel 7 menunjukkan bahwa kelelahan sedang paling banyak dialami oleh pekerja yang memiliki beban kerja berat dan kelelahan berat juga hanya dialami oleh pekerja dengan beban kerja berat. Berdasarkan hasil uji Korelasi Spearman diperoleh nilai $\mathrm{p}$ sebesar 0,031 yang berarti nilai $\mathrm{p}$ lebih kecil dari $\alpha(0,05)$ sehingga dapat disimpulkan bahwa terdapat hubungan antara beban kerja mental dengan kelelahan kerja. Nilai koefisien korelasi yaitu sebesar 0,365 yang menunjukkan bahwa kekuatan hubungan antara beban kerja mental dengan kelelahan kerja termasuk dalam kategori lemah dan bersifat searah yakni semakin tinggi beban kerja yang dirasakan maka semakin berat kelelahan yang dirasakan.

\section{Hubungan Lingkungan Kerja dengan Kelelahan Kerja}

Tabel 8 menunjukkan bahwa kelelahan sedang paling banyak dialami oleh pekerja yang merasa nyaman dengan suhu lingkungan kerjanya, sedangkan kelelahan berat paling banyak dialami oleh pekerja yang merasa tidak nyaman dengan suhu lingkungan kerjanya. Berdasarkan hasil uji Korelasi Spearman diperoleh nilai p sebesar 0,042 yang berarti nilai $p$ lebih kecil dari $\alpha(0,05)$ sehingga dapat disimpulkan bahwa terdapat hubungan antara suhu dengan kelelahan kerja. Nilai koefisien korelasi yaitu sebesar -0,346 yang menunjukkan bahwa kekuatan hubungan antara suhu dengan kelelahan kerja termasuk dalam kategori lemah dan bersifat berlawanan arah yakni semakin banyak pekerja yang tidak nyaman akibat suhu maka semakin banyak pekerja yang merasakan kelelahan kerja berat.

Tabel 9 menunjukkan bahwa kelelahan tingkat sedang paling banyak dialami oleh pekerja yang tidak merasa terganggu dengan kebisingan di

Tabel 7. Hubungan antara Beban Kerja dengan Kelelahan Kerja pada Pekerja Unit Processing Koperasi KAREB Bojonegoro Tahun 2017

\begin{tabular}{|c|c|c|c|c|c|c|c|c|}
\hline \multirow{3}{*}{ Beban Kerja } & \multicolumn{6}{|c|}{ Kelelahan Kerja } & \multirow{2}{*}{\multicolumn{2}{|c|}{ Total }} \\
\hline & \multicolumn{2}{|c|}{ Ringan } & \multicolumn{2}{|c|}{ Sedang } & \multicolumn{2}{|c|}{ Berat } & & \\
\hline & $\mathbf{n}$ & $\%$ & $\mathbf{n}$ & $\%$ & $\mathbf{n}$ & $\%$ & $\mathbf{N}$ & $\%$ \\
\hline Ringan & 0 & 0 & 0 & 0 & 0 & 0 & 0 & 0 \\
\hline Sedang & 6 & 17,1 & 6 & 17,1 & 0 & 0 & 12 & 34,3 \\
\hline Berat & 4 & 11,4 & 17 & 48,6 & 2 & 5,7 & 23 & 65,7 \\
\hline Total & 10 & 28,6 & 23 & 65,7 & 2 & 5,7 & 35 & 100 \\
\hline
\end{tabular}

Tabel 8. Hubungan Antara Suhu dengan Kelelahan Kerja pada Pekerja Unit Processing Koperasi KAREB Bojonegoro Tahun 2017

\begin{tabular}{|c|c|c|c|c|c|c|c|c|}
\hline \multirow{3}{*}{ Suhu } & \multicolumn{6}{|c|}{ Kelelahan Kerja } & \multirow{2}{*}{\multicolumn{2}{|c|}{ Total }} \\
\hline & \multicolumn{2}{|c|}{ Ringan } & \multicolumn{2}{|c|}{ Sedang } & \multicolumn{2}{|c|}{ Berat } & & \\
\hline & $\mathbf{n}$ & $\%$ & $\mathbf{n}$ & $\%$ & $\mathbf{n}$ & $\%$ & $\mathbf{N}$ & $\%$ \\
\hline Tidak Nyaman & 1 & 2,9 & 6 & 17,1 & 2 & 5,7 & 9 & 25,7 \\
\hline Nyaman & 9 & 25,7 & 17 & 48,6 & 0 & 0 & 26 & 74,3 \\
\hline Total & 10 & 28,6 & 23 & 65,7 & 2 & 5,7 & 35 & 100 \\
\hline
\end{tabular}


Tabel 9. Hubungan Kebisingan dengan Kelelahan Kerja pada Pekerja Unit Processing Koperasi KAREB Bojonegoro Tahun 2017

\begin{tabular}{|c|c|c|c|c|c|c|c|c|}
\hline \multirow{3}{*}{ Kebisingan } & \multicolumn{6}{|c|}{ Kelelahan Kerja } & \multirow{2}{*}{\multicolumn{2}{|c|}{ Total }} \\
\hline & \multicolumn{2}{|c|}{ Ringan } & \multicolumn{2}{|c|}{ Sedang } & \multicolumn{2}{|c|}{ Berat } & & \\
\hline & $\mathbf{n}$ & $\%$ & $\mathbf{n}$ & $\%$ & $\mathbf{n}$ & $\%$ & $\mathbf{N}$ & $\%$ \\
\hline Terganggu & 6 & 17,1 & 10 & 28,6 & 2 & 5,7 & 18 & 51,4 \\
\hline Tidak Terganggu & 4 & 11,4 & 13 & 37,1 & 0 & 0 & 17 & 48,6 \\
\hline Total & 10 & 28,6 & 23 & 65,7 & 2 & 5,7 & 35 & 100 \\
\hline
\end{tabular}

lingkungan kerjanya, sedangkan kelelahan berat paling banyak dialami oleh pekerja yang merasa terganggu dengan kebisingan di lingkungan kerjanya. Berdasarkan hasil uji Korelasi Spearman diperoleh nilai $\mathrm{p}$ sebesar 0,938 yang berarti nilai $\mathrm{p}$ lebih besar dari $\alpha(0,05)$ sehingga dapat disimpulkan bahwa tidak terdapat hubungan antara kebisingan dengan kelelahan kerja.

\section{PEMBAHASAN}

\section{Karakteristik Responden}

Berdasarkan hasil penelitian diketahui bahwa sebagian besar responden $(71,4 \%)$ berjenis kelamin laki-laki dan sisanya $(28,6 \%)$ berjenis kelamin perempuan. Berdasarkan hasil penelitian dapat dilihat bahwa sebagian pekerja berjenis kelamin perempuan. Menurut Tarwaka dan Sudiajeng (2004) pekerja perempuan memerlukan perhatian lebih dibanding pekerja laki-laki sebab perempuan pada umumnya hanya memiliki kemampuan fisik sebesar 2/3 dari kemampuan fisik atau kekuatan otot lakilaki. Walaupun demikian, dalam hal ketelitian perempuan lebih unggul daripada laki-laki.

Menurut Konz (1996) perempuan memiliki $\mathrm{VO}_{2}$ max 15-30\% lebih rendah dibandingkan dengan laki-laki untuk melakukan kerja fisik. Presentasi lemak tubuh perempuan juga cenderung lebih tinggi dibandingkan laki-laki dan kadar $\mathrm{Hb}$ darah perempuan juga lebih rendah daripada laki-laki. Kondisi tersebut membuat sesorang yang berjenis kelamin perempuan cenderung lebih mudah lelah dibandingkan dengan laki-laki.

Menurut Priatna (1990) wanita lebih tahan terhadap suhu dingin dari suhu panas karena wanita mempunyai jaringan yang memiliki daya konduksi lebih tinggi terhadap panas jika dibandingkan dengan laki-laki. Akibatnya pada pekerja wanita akan lebih banyak menimbulkan reaksi perifer jika bekerja di lingkungan bersuhu panas seperti lebih mudah lelah yang berakibat pada penurunan daya kerja. Pekerja perempuan di Unit Processing Koperasi Kareb perlu mendapat perhatian khusus seperti pemberian tugas yang disesuaikan dengan kapasitas kerja perempuan.

Karakteristik responden lain yang diteliti adalah umur. Berdasarkan hasil penelitian diketahui bahwa umur pekerja Unit Processing Koperasi KAREB Bojonegoro pada tahun 2017 berkisar antara 35 hingga 57 tahun. Menurut Grandjean (1993) Kapasitas kerja fisik seseorang mencapai puncaknya pada umur 25-30 tahun dan mulai menurun setelah umur 30 tahun. Ketika mencapai umur 50-60 tahun kekuatan otot akan menurun sebesar $25 \%$ dan kemampuan sensoris-motoris menurun sebanyak $60 \%$. Hal itu menunjukkan bahwa kapasitas kerja fisik responden mulai menurun dikarenakan umur mereka yang telah melebihi 30 tahun sehingga mereka lebih rentan mengalami kelelahan.

Grandjean (1993) menyatakan bahwa semakin bertambahnya usia maka kapasitas kerja fisik seseorang akan semakin menurun akibat berkurangnya $\mathrm{VO}_{2}$ max, tajam penglihatan, pendengaran, kecepatan membedakan sesuatu, membuat keputusan, dan kemampuan mengingat jangka pendek yang akan berdampak pada peningkatan risiko mengalami kelelahan.

\section{Kelelahan Kerja}

Berdasarkan hasil analisis data diketahui bahwa 28,6\% pekerja Unit Processing Koperasi KAREB Bojonegoro mengalami kelelahan ringan, 65,7\% pekerja mengalami kelelahan sedang, dan 5,7\% pekerja mengalami kelelahan berat. Pekerja Unit Processing Koperasi KAREB Bojonegoro yang mengalami kelelahan ringan dapat diartikan mereka bekerja dalam keadaan normal seperti pada teori yang dikemukakan oleh Tarwaka dan Sudiajeng (2004) sehingga belum perlu dilakukan tindakan 
perbaikan. Tindakan perbaikan mulai diperlukan pada pekerja dengan tingkat kelelahan sedang sampai berat maupun sangat berat.

Hasil penelitian menunjukkan bahwa sebagian besar pekerja mengalami kelelahan sedang dan bahkan ada yang mengalami kelelahan berat. Hal ini menunjukkan bahwa perlu adanya tindakan perbaikan untuk mengendalikan kelelahan kerja di Unit Processing Koperasi KAREB Bojonegoro. Kelelahan kerja yang dialami oleh pekerja dapat mengakibatkan berkurangnya kemampuan pekerja dalam mengambil keputusan, berkurangnya konsentrasi, waktu reaksi dan daya ingat yang akhirnya akan berdampak pada penurunan kinerja atau produktivitas pekerja. Selain itu juga dapat meningkatkan angka near miss bahkan kecelakaan kerja, absenteisme, kelalaian, dan kesalahan dalam mengambil keputusan (Alberta Government, 2017). Kelelahan yang dialami oleh pekerja Unit Processing Koperasi KAREB dapat disebabkan oleh berbagai faktor, diantaranya yaitu motivasi, beban kerja dan lingkungan kerja.

\section{Hubungan Motivasi dengan Kelelahan Kerja}

Motivasi menurut Uno (2007) adalah kondisi internal dari dalam diri seseorang yang membangkitkan orang tersebut untuk bertindak, mendorong seseorang mencapai target tertentu, dan membuat seseorang tetap tertarik untuk melakukan suatu kegiatan. Berdasarkan hasil uji statistik diperoleh hasil bahwa terdapat hubungan yang cukup kuat antara motivasi kerja dengan kelelahan kerja, dengan sifat hubungan yang berlawanan arah sehingga dapat diasumsikan bahwa semakin rendah motivasi kerja maka semakin berat kelelahan yang dirasakan.

Hasil penelitian ini sesuai dengan Robert (1999) dalam Tarwaka dan Sudiajeng (2004) yang menyatakan bahwa motivasi berpengaruh terhadap kelelahan akibat kerja. Motivasi secara tidak langsung berpengaruh pada kelelahan akibat kerja melalui beban kerja, stres kerja, dan kapasitas kerjanya. Pekerja yang memiliki motivasi rendah akan merasa terbebani secara psikologis dalam melakukan pekerjaannya sehingga lebih mudah merasa lelah. Pekerja yang memiliki motivasi tinggi tidak akan mudah terasa terbebani dalam melaksanakan pekerjaannya sehingga pekerja tersebut juga tidak mudah merasakan lelah. Hasil penelitian ini juga sejalan dengan penelitian Diosma (2015) yang menunjukkan adanya hubungan antara motivasi kerja dengan kelelahan kerja.

\section{Hubungan antara Beban Kerja dengan Kelelahan Kerja}

Beban kerja adalah volume pekerjaan baik berupa fisik ataupun mental yang dibebankan pada pekerja dan menjadi tanggung jawabnya. Pekerjaan yang bersifat berat membutuhkan waktu istirahat yang lebih sering dan waktu kerja yang lebih pendek agar tidak terjadi kelelahan kerja (Suma'mur, 2009).

Kelelahan kerja dapat dikaitkan dengan beban kerjanya. Berdasarkan hasil uji statistik diperoleh hasil bahwa terdapat hubungan antara beban kerja dengan kelelahan kerja. Kekuatan hubungan bersifat lemah dan berlawanan arah sehingga dapat diasumsikan bahwa semakin berat beban kerja seseorang maka akan semakin berat kelelahan yang dialaminya.

Hasil penelitian ini sesuai dengan teori Suma'mur (2009) yang menyatakan bahwa beban kerja yang berat dapat meningkatkan risiko timbulnya kelelahan. Hasil penelitian ini juga sejalan dengan penelitian Kirana (2016) yang menunjukkan adanya hubungan antara beban kerja dengan kelelahan kerja. Selain itu juga sesuai dengan penelitian Wati (2011) yang menunjukkan adanya hubungan antara beban kerja dengan kelelahan kerja.

Kelelahan kerja dapat dikaitkan dengan beban kerja dan waktu istirahat pekerja yang bersangkutan. Berdasarkan hasil penelitian diketahui bahwa kelelahan kerja berat hanya dialami oleh pekerja dengan beban kerja berat dan sebagian besar pekerja merasa memiliki beban kerja yang berat. Pekerja di Unit Processing Koperasi Kareb Bojonegoro dituntut untuk bekerja selama 7 jam penuh tanpa ada jam istirahat sedangkan pekerjaan yang bersifat berat membutuhkan istirahat yang lebih sering dan waktu kerja yang lebih pendek, apabila kebutuhan tersebut tidak terpenuhi maka dapat menimbulkan kelelahan pada pekerja. Kelelahan kerja terjadi pada pekerja di Unit Processing Koperasi Kareb Bojonegoro karena dengan beban kerja mereka yang berat sedangkan kebutuhan akan istirahat tidak tercukupi.

\section{Hubungan antara Lingkungan Kerja dengan Kelelahan kerja}

Hasil uji statistik menunjukkan bahwa terdapat hubungan antara persepsi suhu lingkungan kerja dengan kelelahan kerja. Hal ini sesuai dengan teori Suma'mur yang menyatakan bahwa salah satu akar masalah kelelahan kerja yaitu lingkungan kerja 
termasuk suhu yang tidak sejalan estimasi pekerja. Hasil penelitian ini juga sejalan dengan penelitian Lestari (2016) yang menyatakan bahwa terdapat hubungan antara suhu lingkungan kerja dengan kelelahan kerja.

Berdasarkan data hasil pengukuran suhu lingkungan kerja yang diperoleh dari dokumen pengukuran lingkungan kerja milik Koperasi KAREB, suhu ruang produksi tempat pekerja Unit Processing bekerja yaitu mencapai $36^{\circ} \mathrm{C}$. Suhu tersebut dinilai telah melampaui NAB untuk lingkungan industri menurut Keputusan Menteri Kesehatan No. 1405 Tahun 2002 yaitu $30^{\circ} \mathrm{C}$. Suhu ruangan tersebut juga telah melampaui suhu nyaman bagi orang Indonesia yaitu $24-26^{\circ} \mathrm{C}$. Kondisi tersebut menunjukkan bahwa seluruh pekerja di Unit Processing terpapar suhu panas yang melebihi NAB dan suhu nyaman bagi orang Indonesia.

Berdasarkan hasil penelitian dapat dilihat bahwa sebagian besar pekerja $(74,3 \%)$ sudah merasa nyaman dengan suhu lingkungan kerjanya walaupun suhu tersebut melebihi NAB dan tidak sesuai dengan suhu nyaman bagi orang Indonesia. Hal ini sesuai dengan teori Suma'mur (2009) yang menyatakan walaupun telah ditetapkan $\mathrm{NAB}$ dan suhu nyaman bagi orang Indonesia, namun suhu nyaman untuk setiap individu dapat berbeda-beda dan ada kemungkinan tidak sesuai dengan NAB. Oleh sebab itu standar suhu lingkungan kerja yang digunakan untuk mengendalikan kelelahan kerja tidak lagi menggunakan $\mathrm{NAB}$ namun menggunakan kenyamanan faktor manusia dalam melakukan pekerjaanya.

Berdasarkan hasil wawancara, sebagian besar pekerja telah merasa nyaman dengan kondisi suhu lingkungan kerjanya karena pekerja mengaku telah terbiasa dengan kondisi tersebut. Proses adaptasi fisiologis dengan suhu lingkungan kerja memerlukan waktu 7 hingga 10 hari, sedangkan masa kerja pekerja Unit Processing sudah jauh melebihi 10 hari dan tergolong lama yaitu dalam rentang antara 15 sampai 37 tahun sehingga mereka sudah mampu beradaptasi secara fisiologis dengan lingkungan kerjanya.

Berdasarkan hasil uji statistik diperoleh hasil bahwa tidak terdapat hubungan antara kebisingan dengan kelelahan kerja. Hal ini tidak sesuai dengan teori Tarwaka dan Sudiajeng (2004) yang menyatakan bahwa kebisingan dapat mempengaruhi timbulnya kelelahan kerja. Hasil penelitian tersebut sejalan dengan penelitian Andriani (2016) yang menunjukkan bahwa tidak ada hubungan antara kebisingan dengan kelelahan kerja.

Suma'mur (2009) mendefinisikan kebisingan sebagai bunyi atau suara yang keberadaannya tidak dikehendaki. Penilaian bising bagi setiap orang dapat berbeda-beda karena setiap orang memiliki persepsi tersendiri mengenai suara yang tidak mereka kehendaki.

Berdasarkan data hasil pengukuran kebisingan yang diperoleh dari dokumen hasil pengukuran lingkungan kerja milik Koperasi KAREB, intensitas kebisingan ruang produksi tempat pekerja Unit Processing bekerja yaitu mencapai $81,8 \mathrm{~dB}$. Angka tersebut dinilai masih di bawah NAB kebisingan menurut Permenakertrans No. 13 tahun 2011 yaitu $85 \mathrm{~dB}$. Intensitas kebisingan tersebut termasuk dalam kategori sangat hiruk menurut Suma'mur (2009) sehingga berpotensi menimbulkan gangguan kenyamanan. Oleh sebab itu sebagian besar pekerja di Unit Processing merasa terganggu dengan kebisingan di lingkungan kerjanya.

Kebisingan dengan intensitas rendah atau di bawah NAB secara fisiologis tidak menyebabkan kerusakan pada indera pendengaran namun kehadirannya dapat menyebabkan penurunan performasi kerja, stres, dan gangguan kesehatan lainnya. Stres yang disebabkan oleh paparan kebisingan dapat menyebabkan timbulnya kelelahan, kegelisahan, dan depresi (Tarwaka dan Sudiajeng, 2004).

\section{SIMPULAN}

Pekerja di Unit Processing Koperasi KAREB Bojonegoro sebagian besar mengalami kelelahan kerja tingkat sedang. Terdapat hubungan antara motivasi dengan kelelahan kerja berdasarkan uji statistik dengan nilai $\mathrm{p}=0,004$ ( $p$-value $<0,05)$. Terdapat hubungan antara faktor tuntutan tugas yaitu pada variabel beban kerja dengan kelelahan kerja dengan nilai $\mathrm{p}=0,031$ ( $p$-value $<0,05)$. Terdapat hubungan antara faktor lingkungan kerja pada variabel suhu dengan kelelahan kerja dengan nilai $\mathrm{p}=0,042(p$-value $<0,05)$, sedangkan untuk variabel kebisingan tidak ditemukan adanya hubungan dengan kelelahan kerja.

\section{DAFTAR PUSTAKA}

Alberta Government, 2017. Fatigue, Exteded Work Hours and Workplace Safety. Alberta: Government of Alberta. 
Andriani, KW., 2016. Hubungan Temperatur dan Kebisingan dengan Kelelahan Kerja Subjektif Individu di PT X Jakarta. Skripsi. Universitas Airlangga Surabaya.

Diosma, FF., 2015. Hubungan Motivasi dengan Stres Kerja dan Kelelahan Kerja (Studi di UD Sumber Barokah Sidoarjo, Jawa Timur). Skripsi. Surabaya: Fakultas Kesehatan Masyarakat Universitas Airlangga.

Grandjean, E., 1993. Fitting the Task to the Man, 4th edt. London: Taylor \& Francis Inc.

ILO., 2013. Keselamatan dan Kesehatan Kerja Sarana dan Produktivitas. Geneva: International Labour Organization.

Keputusan Menteri Kesehatan Republik Indonesia Nomor 1405 Tahun 2002 tentang Persyaratan Kesehatan Lingkungan Kerja Perkantoran. Jakarta: Kementerian Kesehatan.

Kirana, VDC., 2016. Analisa Hubungan Beban Kerja dan Stres Kerja dengan Kelelahan pada Perawat di Instalasi Rawat Inap Rumah Sakit Jiwa Menur Surabaya. Skripsi. Surabaya: Fakultas Kesehatan Masyarakat Universitas Airlangga .

Konz, S., 1996. Physiology of Body Movement. Dalam: Battacharya, A. \& McGlothlin, J.D. eds. Occupational Ergonomic. USA: Marcel Dekker Inc.

Lestari, DP., 2016. Hubungan Faktor Lingkungan Kerja dengan Kelelahan Kerja pada Pekerja Unit 1 Boiler PJB Tanjung Awar-Awar. Skripsi. Surabaya: Fakultas Kesehatan Masyarakat Universitas Airlangga.
Nugraheni, AB., 2015. Hubungan Antara Beban Kerja Fisik dengan Kelelahan Kerja pada Tenaga Kerja Bagian Produksi Tulangan Beton di PT. Wijaya Karya Beton Tbk. PPB Majalengka. Skripsi. Surakarta: Universitas Muhammadiyah Surakarta.

Peraturan Menteri Ketenagakerjaan dan Transmigrasi Nomor 13 tahun 2011 tentang Nilai Ambang Batas Faktor Fisika dan Faktor Kimia di Tempat Kerja. Jakarta: Kementerian Tenaga Kerja \& Transmigrasi.

Priatna, BL., 1990. Pengaruh Cuaca Kerja terhadap Berat Badan. Majalah Hiperkes dan Keselamatan Kerja. Jakarta. Vol XXIII (3): 39-49.

Setyowati, DL., 2014. Penyebab Kelelahan Kerja pada Pekerja Mebel. Jurnal Kesehatan Masyarakat Nasional. VIII(8): 386-392.

Suma'mur., 2009. Higiene Perusahaan dan Kesehatan Kerja (Hiperkes). Jakarta: CV. Agung Seto.

Tarwaka, B., Sudiajeng, L., 2004. Ergonomi untuk Keselamatan, Kesehatan Kerja dan Produktivitas. Surakarta: Uniba Press.

Tarwaka, B., 2014. Ergonomi Industri: Dasar-Dasar Ergonomi dan Implementasi di Tempat Kerja. Surakarta: Harapan Press.

Undang-Undang No. 1 Tahun 1970 tentang Keselamatan Kerja. Jakarta: Departemen Perburuhan.

Uno, HB., 2007. Teori Motivasi dan Pengukurannya. Jakarta: Bumi Aksara.

Wati, M., 2011. Hubungan Antara Beban Kerja dengan Kelelahan Kerja Karyawan Laundry di Kelurahan Warungboto Kecamatan Umbulharjo Kota Yogyakarta. Jurnal Kesehatan Masyarakat. Vol. V(1): 162-232. 